\title{
Global forest restoration and the importance of prioritizing local communities
}

DOI:

10.1038/s41559-020-01282-2

\section{Document Version}

Accepted author manuscript

Link to publication record in Manchester Research Explorer

\section{Citation for published version (APA):}

Erbaugh, J. T., Pradhan, N., Adams, J., Oldekop, J. A., Agrawal, A., Brockington, D., Pritchard, R., \& Chhatre, A. (2020). Global forest restoration and the importance of prioritizing local communities. Nature Ecology \& Evolution , 4(11), 1472-1476. https://doi.org/10.1038/s41559-020-01282-2

\section{Published in:}

Nature Ecology \& Evolution

\section{Citing this paper}

Please note that where the full-text provided on Manchester Research Explorer is the Author Accepted Manuscript or Proof version this may differ from the final Published version. If citing, it is advised that you check and use the publisher's definitive version.

\section{General rights}

Copyright and moral rights for the publications made accessible in the Research Explorer are retained by the authors and/or other copyright owners and it is a condition of accessing publications that users recognise and abide by the legal requirements associated with these rights.

\section{Takedown policy}

If you believe that this document breaches copyright please refer to the University of Manchester's Takedown Procedures [http://man.ac.uk/04Y6Bo] or contact uml.scholarlycommunications@manchester.ac.uk providing relevant details, so we can investigate your claim.

\section{OPEN ACCESS}




\title{
Global Forest Restoration and the Importance of Prioritizing Local Communities
}

\author{
J. T. Erbaugh ${ }^{1 *}$, N. Pradhan ${ }^{2}$, J. Adams ${ }^{3}$, J. A. Oldekop ${ }^{4}$, A. Agrawal ${ }^{5}$, D. Brockington ${ }^{6}$, R. \\ Pritchard $^{4,6}$, A. Chhatre ${ }^{2}$ \\ ${ }^{1}$ Department of Environmental Studies, Dartmouth College, USA \\ ${ }^{2}$ Bharti Institute of Public Policy, Indian School of Business, India \\ ${ }^{3}$ Dartmouth Library, Dartmouth College, USA \\ ${ }^{4}$ Global Development Institute, University of Manchester, UK \\ ${ }^{5}$ School of Environment and Sustainability, University of Michigan, USA \\ ${ }^{6}$ Sheffield Institute for International Development, University of Sheffield, UK \\ * Correspondence to: james.t.erbaugh@dartmouth.edu.
}

\begin{abstract}
Forest restoration occupies center stage in global conversations about carbon removal and biodiversity conservation, but recent research rarely acknowledges social dimensions or environmental justice implications related to its implementation. We find that 294.5 million people live on tropical forest restoration opportunity land in the Global South, including 12\% of the total population in low-income countries. Forest landscape restoration that prioritizes local communities by affording them rights to manage and restore forests provides a promising option to align global agendas for climate mitigation, conservation, environmental justice, and sustainable development.
\end{abstract}




\section{Main}

Forest restoration is considered a crucial strategy for conserving global biodiversity and mitigating climate change ${ }^{1-3}$. New research identifies the global extent of forest restoration opportunities, demonstrates the promise of forest restoration for mitigating climate change, and calls for more ambitious global forest restoration efforts ${ }^{1-6}$. There is some disagreement about the degree to which forest restoration can or should contribute to atmospheric carbon removal ${ }^{7-9}$, as mitigating climate change depends on decarbonizing the economy while protecting intact forests and restoring degraded landscapes ${ }^{10}$. Yet prominent conservation initiatives such as "global no net loss" of natural ecosystems, "half for nature," and the Aichi Target 11 still combine conservation of intact natural habitat and restoring degraded forests to reach their ambitious targets $^{11-13}$.

To progress those goals, recent research on forest restoration advances conservation and climate mitigation agendas with knowledge about where trees can be grown and the global potential for restoration. It often fails, however, to address the social implications of global forest restoration. In this communication, we argue that the success of global forest restoration critically depends on prioritizing local communities ${ }^{14}$.

To realize its full potential, forest restoration cannot avoid rural populations. Confining restoration efforts to sparsely inhabited forest landscapes removes the concern of displacing or marginalizing local populations, but it limits global restoration in three ways. First, remote restoration regions ( 1 person $/ \mathrm{km}^{2}$ or less within a $500 \mathrm{~km}$ radius) represent only $11 \%$ of global forest restoration opportunity areas ${ }^{15}$. Second, because remote forest restoration is only possible in areas far from human settlements, fewer people will enjoy any local benefits. Third, only pursuing remote forest restoration would not contribute as meaningfully to biodiversity 
conservation. The tropics are home to a disproportionate amount of the world's biodiversity but contain only $0.68 \%$ of all remote restoration opportunities. Remote forest restoration holds promise for carbon sequestration, but global agendas that seek to deliver the greatest number of benefits from forest restoration will need to focus on populated landscapes ${ }^{5}$.

Forest restoration initiatives must, therefore, identify how best to work with local communities. Approaches that exclude indigenous people and local communities, including some protected areas, have been associated with environmental conflicts, poor conservation performance, and negative social outcomes ${ }^{16-18}$. Restoring forests without the consent of those who depend on the same land will likely lead to forced displacement (physical or economic), and/or costly monitoring and regulation to prohibit illegal (though often legitimate) activities.

Excluding indigenous people and local people from forest restoration also poses ethical problems. Such exclusion would force some of the most multidimensionally poor people - those who live in rural areas within low-income countries - to move or sacrifice their current livelihood for a global carbon and biodiversity debt to which they contributed little ${ }^{19}$. Just and equitable climate mitigation and biodiversity conservation from forest restoration requires the inclusion and participation of local communities ${ }^{20,21}$.

As a mechanism of land and resource management, Forest Landscape Restoration (FLR) has considerable potential to include local populations and improve local livelihoods. FLR was initially conceived as a management approach to promote ecological restoration and human wellbeing in degraded landscapes by engaging local stakeholders ${ }^{22}$. By including local stakeholders from the public, private, and civil society sectors, proponents assert that FLR contributes to human well-being through the use and sale of forest products, increases in food as well as water security, and through diverse cultural values people hold for trees and forests ${ }^{21-25}$. However, 
competing definitions of FLR exist ${ }^{26}$. The Bonn Challenge to commence restoration of 350 million ha of forest landscapes by 2030 refers to FLR as large-scale forest restoration projects but does not emphasize the importance of engaging local stakeholders in planning and implementation processes ${ }^{2,27,28}$. Thus, many current debates about FLR reflect a lack of conceptual clarity and do not adequately address recent evidence as to how forest restoration can promote ecological as well as human well-being ${ }^{24,29}$. In this text, we define FLR as an approach to landscape planning and management that aims to restore ecological integrity and enhance human well-being on deforested and degraded lands through the inclusion and engagement of local stakeholders ${ }^{22}$.

To unite global agendas for climate mitigation, conservation, and environmental justice, FLR must go beyond merely including local stakeholders and prioritize local communities. Given the uncertainty surrounding forest restoration and its impacts on human well-being ${ }^{30-32}$, the tendency to implement restoration without consulting local stakeholders is untenable ${ }^{33}$. Consulting local stakeholders alone does not guarantee just and equitable forest restoration. However, there are numerous examples in the conservation sector where indigenous people and local communities have generated positive human and environmental outcomes when afforded rights to manage and use forests ${ }^{16,34}$. Technical training and equitable resource access reduces some risks associated with community resource management, including elite capture, overharvests, and exclusion ${ }^{35}$. In many contexts, empowering communities to manage forests for restoration provides a reasonable and just approach to address contextual uncertainty, incorporate traditional ecological knowledge, and assist forest proximate populations to receive the opportunities they desire from global restoration ${ }^{28,36,37}$. 
The potential synergies from prioritizing local communities through FLR emphasize the importance of determining where forest restoration, human populations, and development intersect. Our analysis examines the overlap between opportunities for tropical forest restoration, human populations, development, and national policies for community forest ownership to identify where focusing forest restoration efforts might best benefit both people and the planet. We focus on the tropics because of the synergies between carbon sequestration, biodiversity conservation, and human well-being benefits that FLR affords there ${ }^{5}$ We aggregate our data to present country-level estimates because nation-states remain primary actors in setting carbon removal and landscape restoration targets ${ }^{2}$.

We find that 294.5 million people live in recently tree-covered areas representing tropical forest restoration opportunities in the Global South. Many more people live near these forest restoration opportunities. One third of the tropical population in our analysis $(\sim 1.01$ billion people) live within eight kilometers of land predicted to enable forest restoration from 20202050, given a moderate carbon tax incentive $\left(\$ 20 \mathrm{tCO}_{2}^{-1}\right)$. Table $\mathrm{S} 1$ provides additional information on population estimates across different forest restoration opportunities and methods.

Forest restoration opportunities, population, and development vary widely by country (Fig. 1). Brazil (BRA), the Democratic Republic of Congo (COD), India (IND), and Indonesia (IDN) have the greatest number of people living in or near $(<8 \mathrm{~km})$ forest restoration opportunity areas with the greatest potential to remove carbon (Fig. 2a). Crafting global FLR strategies that seek to deliver sustainable development benefits to the most local people within the fewest countries would do well to focus on these nations. However, FLR may generate greater population-level benefits in nations where forest restoration opportunities, and the people 
who depend on them, comprise a significant proportion of their respective total population. Political, market, and civil society actors in these same countries are likely to enhance international activity and investment in FLR with national efforts, should restoration provide well-being benefits. Countries with a greater proportion of forest restoration opportunity area include the Democratic Republic of Congo (COD), Tanzania (TZA), the Central African Republic (CAF), and Mozambique (MOZ) (Fig. 2b).

FLR investments hold the promise to improve the livelihood and well-being of millions often underserved by standard investments in infrastructure and development. Within lowincome countries, $12 \%$ of the population lives in forest restoration opportunity areas (Fig. 1c). Forest restoration opportunities exist outside areas of greatest human pressure, and populations in these areas often face greater infrastructural and developmental deprivation. Nighttime light radiance indicates the extent and magnitude of electrical infrastructure and usage, and it is strongly correlated with a host of development indicators ${ }^{38-40}$. Areas in low-income nations with the least nighttime light radiance and the greatest carbon removal potential indicate where FLR might best complement sustainable development agendas. There are many opportunities in central, eastern, and southern Africa to restore forests and provide socioeconomic and infrastructure benefits to local people facing many multidimensional deprivations (Fig. 2 and Supplementary Fig. 1). However, concurrently improving infrastructure and restoring forests does create additional risks, since forest cover loss and degradation often follow infrastructure development ${ }^{41}$. Providing indigenous people and local communities the ability to participate in managing forest landscapes via resource rights can moderate the relationship between improved infrastructure, forest cover loss, and human well-being ${ }^{42}$. 
Most forest restoration opportunity areas and their associated populations exist in countries with legal foundations for community forest ownership. Community forest ownership includes the following rights afforded in perpetuity: forest access, resource withdrawal, exclusion, as well as due process and compensation ${ }^{43}$. As such, ownership represents a stronger set of resource rights than community forest management or access alone. In this analysis, countries with pre-existing legal frameworks and evidence of community forest ownership $(n=22)$ contain two-thirds of forest restoration opportunity areas (Fig. 2 and Supplementary Table 2). Further, countries that provide forest ownership rights to communities contain $70 \%$ of people living in or near forest restoration opportunity areas (Table S2), which represent a large proportion of their total tropical population (Fig. 2a-b). A legal framework for community forest rights and evidence of their recognition do not guarantee faithful implementation of community forest ownership, but their absence indicates forest proximate communities are excluded from making authorized decisions about the future of the forests on which they depend. This implies a greater likelihood of exclusion from forest areas, forest products, and related benefits. Continued efforts to expand community forest ownership are essential, and they are of pressing national importance in countries with a significant proportion of people living in forest restoration opportunity areas, such as the Central African Republic (CAF), the Democratic Republic of Congo (COD), Thailand (THA), and the Lao People's Democratic Republic (LAO) (Fig. 2b). To advance global restoration while prioritizing forest-proximate peoples through community forest rights, FLR must emphasize the importance of locally managed restoration.

FLR that prioritizes local communities represents a just mechanism for global forest restoration. Recent research highlights the importance of forest restoration to climate mitigation agendas, and it advances the ability to locate forest restoration opportunities. It remains essential 
to assess this information in relation to institutional, social, and political circumstances to determine how FLR can best contribute to equitable and sustainable climate solutions. Excluding local communities from global forest restoration limits our ability to mitigate climate change, and it risks resistance, conflict, and perpetuating environmental injustices. Empowering local communities to restore forests can provide human well-being benefits to millions of the most deprived and marginalized people as well as environmental benefits for all.

\section{Methods}

\section{$\underline{\text { Forest restoration opportunity areas }}$}

We combine two datasets to identify areas that represent opportunities for forest restoration. Combining data that classifies forest restoration opportunities using demographic, geographic, and land-cover data with estimates from a land change model that predicts carbon removal from forest restoration provides more conservative estimates of where, and to what extent, forest restoration is likely to mitigate climate change.

We first define forest restoration opportunity areas as wide-scale and mosaic restoration areas in the tropics identified in the "Global map of forest landscape restoration opportunities"15. Wide-scale restoration areas have the potential to support closed forest canopy and contain population densities of less than 10 people $/ \mathrm{km}^{2}$. Mosaic restoration areas are similarly able to support closed forest canopy but contain population densities of between 10 and 100 people $/ \mathrm{km}^{2}$. Forest restoration areas from the "Global map" are identified by layering data. Through this method, deductively determined cut-off points and population densities applied to spatial biophysical and human pressure datasets identify locations most amenable to forest restoration. Other studies of global forest restoration opportunities and land-cover patterns employ this method of spatial identification ${ }^{5,44}$. Among the global set of forest restoration opportunities, we 
focus on opportunities in tropical countries because of the potential these areas have for removing atmospheric carbon, promoting biodiversity conservation, and contributing to the wellbeing of forest proximate people $\mathrm{e}^{3,5}$.

We further define forest restoration opportunities using estimates of where, and to what extent, atmospheric carbon removal from forest restoration would occur given a moderate economic incentive. Estimates of carbon removal come from a land-change model that calculates where a $\$ 20 \mathrm{tCO}_{2}{ }^{-1}$ carbon tax is likely to incentivize forest restoration from $2020-2050$, based on tree cover in 2000 and 2010, topographical variation, as well as agricultural opportunity-costs ${ }^{4}$. Though the model estimates forest restoration and carbon removal using a $\$ 20 \mathrm{tCO}_{2}^{-1}$ scenario, these data broadly represent where a moderate financial incentive equal to or greater than the value generated by a carbon tax is likely to promote forest restoration. Importantly, this approach improves upon many studies that identify forest restoration opportunities through layering because it explicitly models carbon removal from forest restoration as a function of opportunity costs based on prices of regional agricultural products.

The "Global map" and carbon removal spatial datasets differed in extent and resolution. We analyze forest restoration opportunities in the tropics from $23.4^{\circ} \mathrm{N}$ to $15^{\circ} \mathrm{S}$ because both datasets contain information across this spatial extent. Within this extent, the "Global map" data contains pixels measuring 30 arcseconds ( $\sim 1 \mathrm{~km}$ pixels), while the carbon removal dataset contains pixels measuring and 3 arcminutes ( $\sim 5.55 \mathrm{~km}$ pixels). To identify forest restoration opportunities as the union of these datasets, we calculated the percent of "Global map" opportunity areas within each pixel of carbon removal from forest restoration estimated by the land-change model. Country-level aggregates for carbon removal by population, as well as carbon removal by nighttime light radiance, vary in accordance with the "Global map" 
opportunity threshold (Supplementary Fig. 2-5). We present the 30\% threshold findings in the main text to mirror the standard of using $30 \%$ canopy cover to categorize $30 \mathrm{~m}$ pixels as treecovered $^{45}$. However, the findings we report in the main text are largely robust to varying the threshold between $30 \%$ and 50\% of "Global map" opportunity areas (Supplementary Fig. 2-5).

Using mutually informative datasets improves the identification of forest restoration areas and their potential carbon removal. By combining the "Global map" and carbon removal datasets, our findings draw from strengths of both datasets, and avoid (what some have considered) overestimation of forest restoration opportunities in high population density croplands $\left(>100\right.$ people $\left./ \mathrm{km}^{2}\right)$ and native grasslands ${ }^{46,47}$. We dropped all "Global map" opportunity areas with over 100 people $/ \mathrm{km}^{2}$, and our analysis does not include areas without at least $30 \%$ tree-cover in 2000 or $2010^{4}$. Thus, the forest restoration opportunity areas in this research represent estimates of where forest restoration is most likely to occur in regions that were tree-covered in the $21^{\text {st }}$ century. Future research might apply the methods of this analysis to compare estimates across additional datasets that identify additional forest restoration opportunities and global tree carrying capacities ${ }^{1,5}$.

Estimating population, nighttime light radiance, and income categories in FLR areas

We combine forest restoration opportunities with spatial data on population and nighttime light radiance, as well as country-level data on income categories, to provide demographic, infrastructural, and economic insights concerning forest restoration opportunities. Population ${ }^{48}$ and nighttime light radiance data ${ }^{49}$ have the same spatial resolution as data from the "Global map." Thus, we aggregated these data to match our forest restoration opportunity area data. The number of people within restoration opportunity areas measuring 30 arcseconds differed from the number of people within areas measuring 3 arcminutes that provide any carbon 
removal additionality under a $\$ 20 \mathrm{tCO}_{2}{ }^{-1}$ carbon tax. We estimate approximately 294.5 million people live directly within forest restoration opportunity areas (30 arcseconds), over two thirds of the total tropical population (2.37 billion people) in this analysis live within eight kilometers of any predicted carbon removal from forest restoration between $2020-2050$ given in a $\$ 20 \mathrm{tCO}_{2}{ }^{-1}$ incentive, and 1.01 billion people live in forest restoration opportunities identified in this study as a 3 arcminute area with any predicted carbon removed from forest restoration and covered by at least $30 \%$ of mosaic or wide-scale restoration opportunities identified by the "Global map" (Fig. 2). Supplementary Figure 6 visualizes country-level information for forest restoration opportunities defined as the union of the "Global map" and predicted carbon removal data, without imposing a minimum coverage threshold.

The income categories in this research follow the World Bank classification scheme, which categorizes low-income, lower-middle income, and upper-middle income countries by virtue of Gross National Income (GNI) per capita. Low-income countries have a GNI per capita of less than $\$ 1,025$; lower-middle income countries, between $\$ 1,026$ and $\$ 3,995$; and uppermiddle income countries, $\$ 3,996$ and $\$ 12,375^{50}$. For pixel-level visualization, we overlaid country boundaries with high-value restoration areas to determine the related income category per pixel. To calculate the proportion of people per income category within forest restoration opportunity areas (Fig. 1c), we used the total number of people per country, including people who live in areas outside the extent of Fig. 1.

\section{Community resource rights and tenure}

This research considers community tenure to be a bundle of resource rights that enable communities to manage land areas for their own benefit ${ }^{51,52}$. Following the Rights and Resources Initiative, this research divides community forest tenure into two categories ${ }^{43}$. The first category 
is community ownership of forest areas. Community ownership of forest areas provides the rights to access forests, withdraw forest resources, manage forest resources, and exclude others from using resources. Community forest ownership is not limited by the need for renewal or oversight, and communities that own forests have the right to due process and compensation. The second category of community forest tenure refers to a bundle of rights that enable communities to manage forests in perpetuity. Community forest management rights include all the rights of community ownership, except for the right to due process and unlimited duration of rights. Community forest management rights often coincide with co-management governance strategies, where a governmental authority and a group of local people work together to manage forest areas. We further distinguish between countries that have a legal basis for community forest tenure (ownership or designation) and countries for which there is evidence of communities that legally hold tenure rights. We gather evidence from research conducted by the Rights and Resources Initiative $\mathrm{e}^{43,53}$.

Of the 106 low- and middle-income countries in the tropics within this dataset, 73 contained forest restoration opportunities as defined in this research. There are 42 countries that contain a legal basis for community forest tenure ${ }^{43,53}$. Of these 42 countries, 22 contain a legal basis for community forest ownership and provide some evidence of providing those rights. Table S2 highlights these 42 countries, ordered by evidence and legal basis for community forest ownership, evidence and legal basis for community forest designation, and the total amount of FLR opportunity area. All World Bank Country Codes for countries in this analysis are listed in Table S3. 


\section{References}

1. Bastin, J. F. et al. The global tree restoration potential. Science 364, 76-79 (2019).

2. Lewis, S. L., Wheeler, C. E., Mitchard, E. T. A. \& Koch, A. Regenerate natural forests to store carbon. Nature 568, 25-28 (2019).

3. Chazdon, R. L. \& Brancalion, P. Restoring forests as a means to many ends. Science 365, 24-25 (2019).

4. Busch, J. et al. Potential for low-cost carbon dioxide removal through tropical reforestation. Nat. Clim. Chang. 9, 463-466 (2019).

5. Brancalion, P. H. S. et al. Global restoration opportunities in tropical rainforest landscapes. Sci. Adv. 5, eaav3223 (2019).

6. Strassburg, B. B. N. et al. Strategic approaches to restoring ecosystems can triple conservation gains and halve costs. Nat. Ecol. Evol. 3, 62-70 (2019).

7. Friedlingstein, P., Allen, M., Canadell, J. G., Peters, G. P. \& Seneviratne, S. I. Comment on "The global tree restoration potential". Science 366, eaay8060 (2019).

8. Lewis, S. L. et al. Comment on "The global tree restoration potential”. Science 366, eaaz0388 (2019).

9. Veldman, J. W. et al. Comment on "The global tree restoration potential". Science 366, eaay7976 (2019).

10. Anderson, C. M. et al. Natural climate solutions are not enough. Science 363, 933-934 (2019).

11. Maron, M. et al. Global no net loss of natural ecosystems. Nat. Ecol. Evol. 4, (2019).

12. Schleicher, J. et al. Protecting half of the planet could directly affect over one billion people. Nat. Sustain. 2, 1-3 (2019).

13. Mappin, B. et al. Restoration priorities to achieve the global protected area target. Conserv. Lett. 12, 1-9 (2019).

14. Pritchard, R. \& Brockington, D. Forests: regrow with locals’ participation. Nature 569, 630 (2019).

15. Potapov, P., Laestadius, L. \& Minnemeyer, S. Global map of forest landscape restoration opportunities. (2011).

16. Oldekop, J. A., Holmes, G., Harris, W. E. \& Evans, K. L. A global assessment of the social and conservation outcomes of protected areas. Conserv. Biol. 30, 133-141 (2016).

17. Agrawal, A. \& Redford, K. Conservation and displacement: An overview. Conserv. Soc. 7, 1 (2009).

18. Chazdon, R. L. Protecting intact forests requires holistic approaches. Nat. Ecol. Evol. 2, 2018 (2018).

19. Olsson, L. et al. Livelihoods and Poverty. in Climate Change 2014: Impacts, Adaptation, and Vulnerability. Part A: Global and Sectoral Aspects. Contribution of Working Group II to the Fifth Assessment Report of the Intergovernmental Panel on Climate Change (eds. Field, C. B. et al.) 793-832 (2014).

20. Loft, L. et al. Risks to REDD+: Potential pitfalls for policy design and implementation. Environ. Conserv. 44, 44-55 (2017).

21. Brancalion, P. H. S. \& Chazdon, R. L. Beyond hectares: four principles to guide reforestation in the context of tropical forest and landscape restoration. Restor. Ecol. 25, 491-496 (2017).

22. Mansourian, S. Overview of forest restoration strategies and terms. in Forest Restoration in Landscapes: Beyond Planting Trees (eds. Mansourian, S., Vallauri, D. \& Dudley, N.) 8-13 (Springer, 2005). doi:10.1007/0-387-29112-1_2

23. Sabogal, C., Besacier, C. \& McGuire, D. Forest and landscape restoration: Concepts, approaches and challenges for implementation. Unasylva 66, 3-10 (2015).

24. Stanturf, J. A. et al. Implementing forest landscape restoration under the Bonn Challenge: a systematic approach. Ann. For. Sci. 76, (2019).

25. Sayer, J. et al. Ten principles for a landscape approach to reconciling agriculture, conservation, and other 
competing land uses. Proc. Natl. Acad. Sci. U. S. A. 110, 8349-56 (2013).

26. Mansourian, S. In the eye of the beholder : Reconciling interpretations of forest landscape restoration. 28882898 (2018). doi:10.1002/ldr.3014

27. Fagan, M. E., Reid, J. L., Holland, M. B., Drew, J. G. \& Zahawi, R. A. How feasible are global forest restoration commitments? Conserv. Lett. 1-8 (2020). doi:10.1111/conl.12700

28. Mansourian, S., Stanturf, J. A., Derkyi, M. A. A. \& Engel, V. L. Forest Landscape Restoration: increasing the positive impacts of forest restoration or simply the area under tree cover? Restor. Ecol. 25, 178-183 (2017).

29. Mansourian, S. et al. Putting the pieces together: Integration for forest landscape restoration implementation. L. Degrad. Dev. 31, 419-429 (2020).

30. Erbaugh, J. T. \& Oldekop, J. A. Forest landscape restoration for livelihoods and well-being. Curr. Opin. Environ. Sustain. 32, 76-83 (2018).

31. Mansourian, S. \& Parrotta, J. Forest landscape restoration: integrated approaches to support effective implementation. (Routledge, 2018).

32. Adams, C., Rodrigues, S. T., Calmon, M. \& Kumar, C. Impacts of large-scale forest restoration on socioeconomic status and local livelihoods: what we know and do not know. Biotropica 48, 731-744 (2016).

33. Fox, H. \& Cundill, G. Towards increased community-engaged ecological restoration: A review of current practice and future directions. Ecol. Restor. 36, 208-218 (2018).

34. Persha, L., Agrawal, A. \& Chhatre, A. Social and Ecological Synergy: Local Rulemaking, Forest Livelihoods, and Biodiversity Conservation. Science 331, 1606-1608 (2011).

35. Brooks, J. S., Waylen, K. A. \& Mulder, M. B. How national context, project design, and local community characteristics influence success in community-based conservation projects. Proc. Natl. Acad. Sci. U. S. A. 109, 21265-21270 (2012).

36. Boedhihartono, A. K. \& Sayer, J. Forest Landscape Restoration. 15, 309-323 (2012).

37. Chazdon, R. L. et al. A Policy-Driven Knowledge Agenda for Global Forest and Landscape Restoration. Conserv. Lett. 10, 125-132 (2017).

38. Bennett, M. M. \& Smith, L. C. Advances in using multitemporal night-time lights satellite imagery to detect, estimate, and monitor socioeconomic dynamics. Remote Sens. Environ. 192, 176-197 (2017).

39. Proville, J., Zavala-Araiza, D. \& Wagner, G. Night-time lights: A global, long term look at links to socioeconomic trends. PLoS One 12, 1-12 (2017).

40. Kyba, C. C. M. et al. Artificially lit surface of Earth at night increasing in radiance and extent. 1-9 (2017).

41. Soares-Filho, B. S. et al. Modelling conservation in the Amazon basin. Nature 440, 520-523 (2006).

42. Oldekop, J. A., Sims, K. R. E., Karna, B. K., Whittingham, M. J. \& Agrawal, A. Reductions in deforestation and poverty from decentralized forest management in Nepal. Nat. Sustain. 2, 421-428 (2019).

43. Rights and Resources Initiative. At a Crossroads. Consequiental trends in recognition of community-based forest tenure from 2002-2017. (2018).

44. Jones, K. R. et al. One-third of global protected land is under intense human pressure. Science 360, 788-791 (2018).

45. Hansen, M. C. et al. High-resolution global maps of 21st-century forest cover change. Science 342, 850-853 (2013).

46. Veldman, J. W. et al. Where Tree Planting and Forest Expansion are Bad for Biodiversity and Ecosystem Services. Bioscience 65, 1011-1018 (2015).

47. Veldman, J. W. et al. Toward an old-growth concept for grasslands, savannas, and woodlands. Front. Ecol. 
Environ. 13, 154-162 (2015).

48. CIESIN. Gridded Population of the World, Version 4 (GPWv4): Population Count Adjusted to Match 2015 Revision of UN WPP Country Totals, Revision 11. (2018).

49. NOAA. Version 1 VIIRS Day/Night Band Nighttime Lights. (2019).

50. The World Bank. World Development Indicators. (2019).

51. Schlager, E. \& Ostrom, E. Property-Rights Regimes and Natural Resources: A Conceptual Analysis. Land Econ. 68, (1992).

52. Sikor, T., He, J. U. N. \& Lestrelin, G. Property Rights Regimes and Natural Resources: A Conceptual Analysis Revisited. World Dev. 93, 337-349 (2017).

53. Rights and Resources Initiative. Who owns the world's land? A global baseline of formally recognized indigenous and community land rights. (2015).

\section{Acknowledgements}

This work was supported by the Rights and Resources Initiative. J.T.E. undertook this research while supported by the National Science Foundation (grant no. 1912001). We are grateful to J. Busch for providing comments on an earlier version of this manuscript and to A. Frechette, C. Ginsburg, and D. Kroeker-Maus for their research assistance.

\section{Author Contributions}

J.T.E., J.A., J.A.O., and A.C. designed the analyses. J.T.E., J.A., and N.P. compiled the data and conducted the analyses. J.T.E., J.A.O., R.P., D.B., A.A., and A.C. wrote the paper.

\section{Code Availability}

Code for analysis is available at the Harvard Dataverse

(https://doi.org/10.7910/DVN/YUUXKU). The folder contains information on setting up the Docker container to reproduce analysis as well as static versions of software dependencies that are not part of the default Docker image.

\section{Data Availability}

Data for and from this analysis are available at the Harvard Dataverse (https://doi.org/10.7910/DVN/YUUXKU). The folder contains instructions for obtaining all input and output data it does not contain due to size or sharing limitations.

\section{Competing Interests}

The authors declare no competing interests.

\section{Figure Legends}




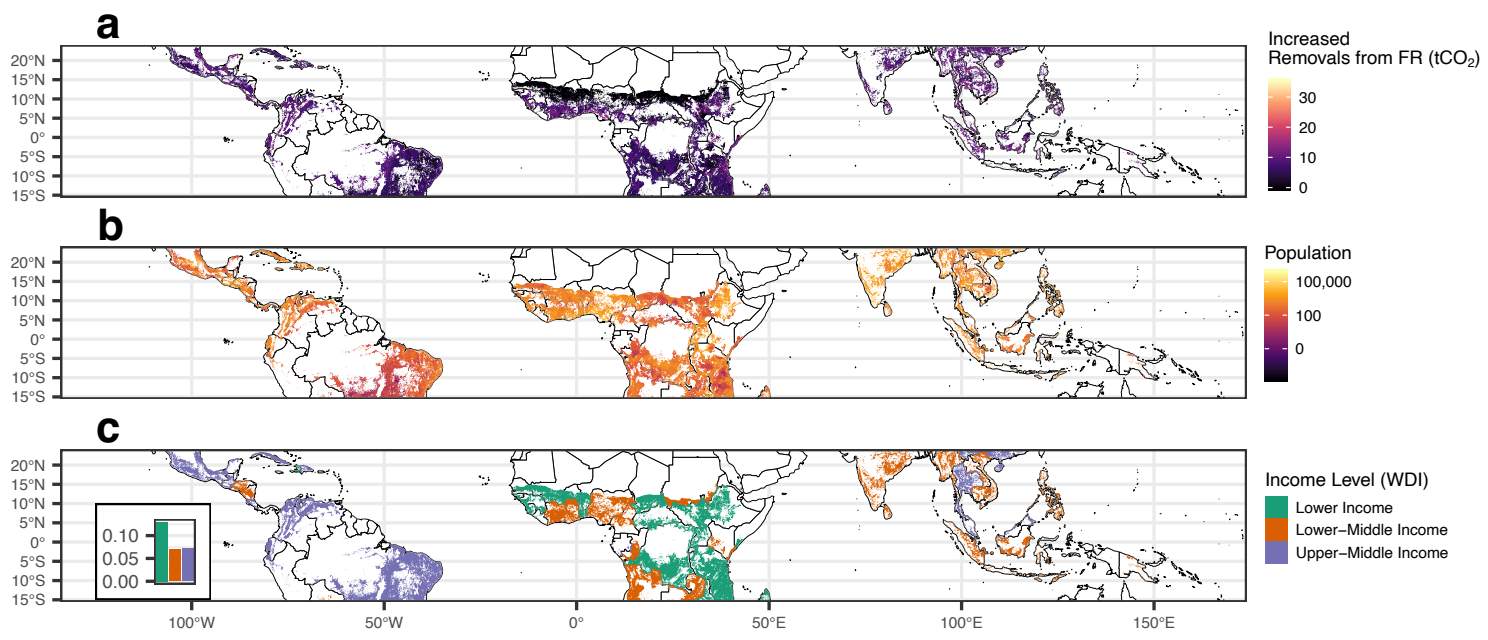

Fig. 1 | Forest restoration (FR) opportunity areas in the tropics. Forest restoration (FR) opportunity areas ${ }^{15}$ by estimated carbon removal from 2020-2050 given a $\$ 20 \mathrm{tCO}_{2}{ }^{-1}$ scenario $^{4}$ (a), FR areas by population density (population $\left./ 5.55 \mathrm{~km}^{2}\right)^{48}(\mathbf{b})$, FR areas by country-level income categories ${ }^{50}(\mathbf{c})$; and the proportion of people living in FR areas by income category (inset). 

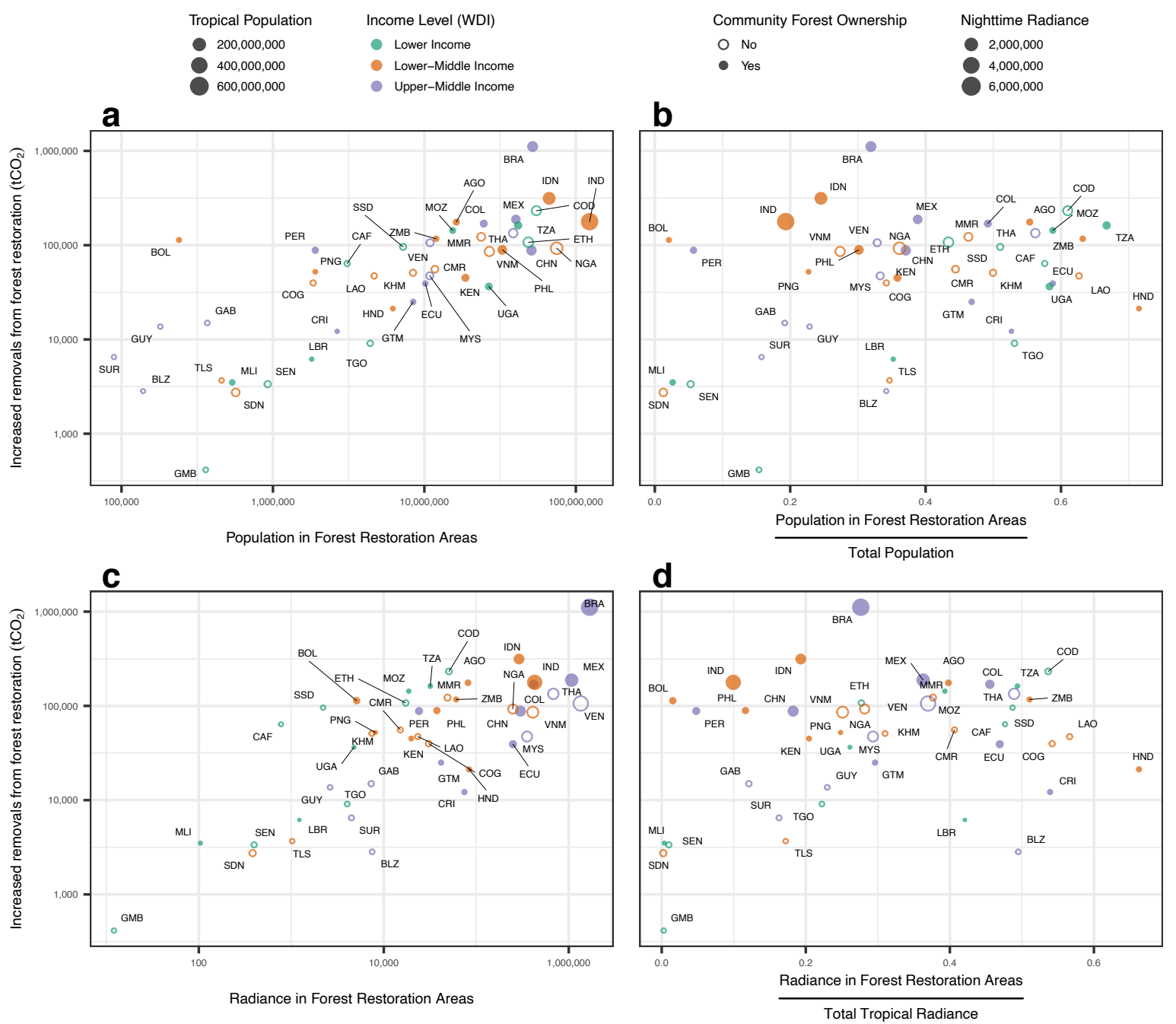

Fig. 2 | Country-level population ${ }^{48}$ and nighttime light radiance ${ }^{49}$ by increased removals from reforestation ${ }^{4}$. Countries are plotted in reference to population in forest restoration (FR) opportunity areas by increased removals from forest restoration in $\mathrm{tCO}_{2}(\mathbf{a})$; the proportion of country population in FR areas by increased removals (b); total nighttime light radiance by increased removals (c); and the proportion of nighttime light radiance in FR areas by total tropical nighttime light radiance $(\mathbf{d})$. Increased removals are predicted under a $\$ 20 \mathrm{tCO}_{2}{ }^{-1} \mathrm{scenario}$ from 2020-2050. Nighttime light radiance is measured in (nanoWatts $/ \mathrm{cm}^{2} / \mathrm{sr}$ ) x $10^{9}$. All panels visualize 45 countries that represent $90 \%$ of the total FLR opportunity area in the tropics. Supplemental information contains plots with all countries $(n=69)$. 


\section{Supplementary Information for}

Global forest restoration and the importance of prioritizing local communities

This file includes:

Supplementary Figures 1-6

Supplementary Tables 1-3 


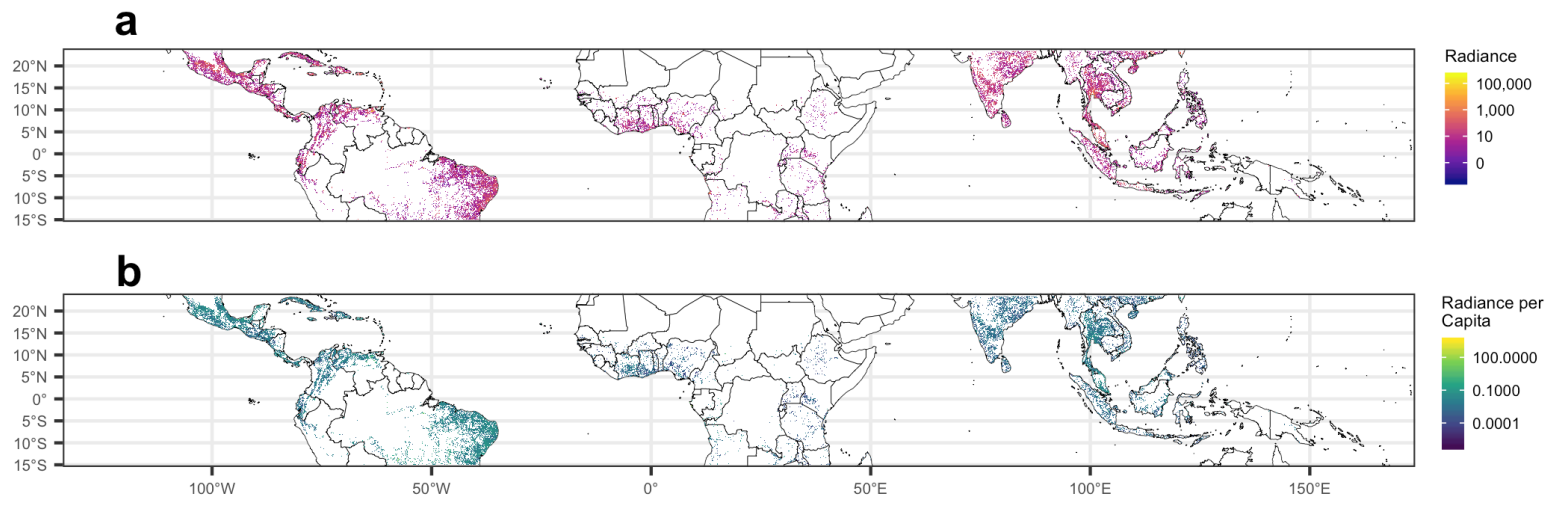

\section{Supplementary Figure 1}

Forest restoration opportunities ${ }^{15}$ by nighttime light radiance ${ }^{49}$ (nanoWatts $/ \mathrm{cm}^{2} / \mathrm{sr}$ ) $\times 1.44^{11}$. Forest restoration opportunity areas are visualized by total pixel-level radiance (a) and by total pixellevel radiance per capita (people $\left./ 5.5 \mathrm{~km}^{2}\right)(\mathrm{b})$. 

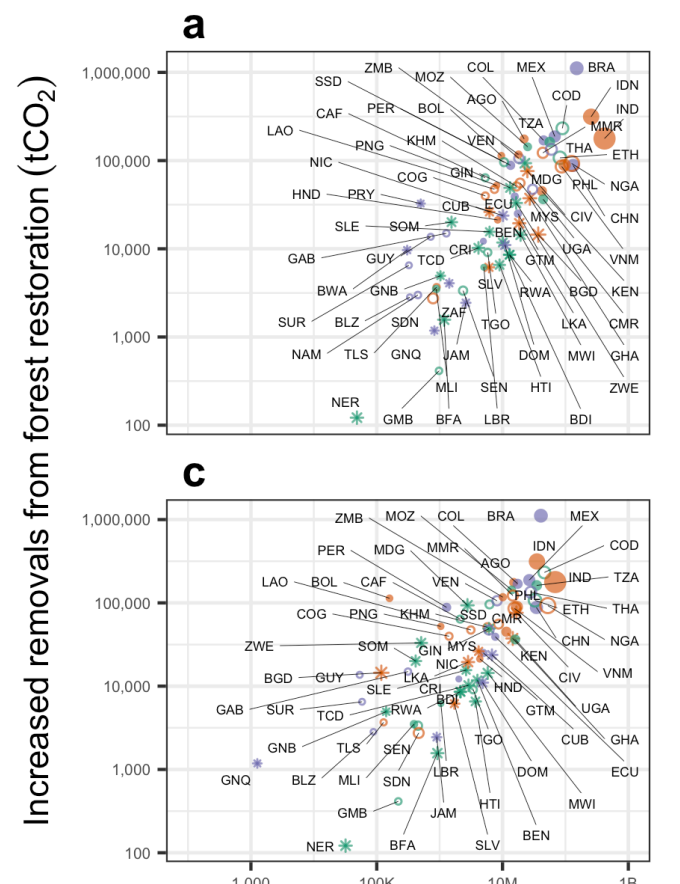

Population in Forest Restoration Areas b

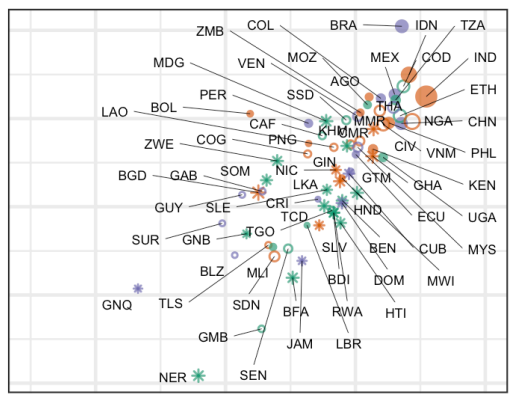

d

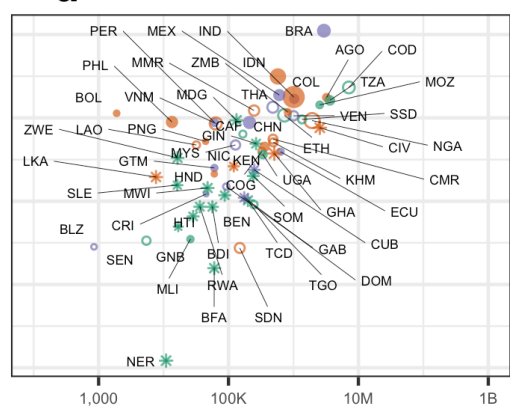

Tropical Population

- $200,000,000$

- $400,000,000$

$600,000,000$

Income Level (WDI)

- Lower Income

- Lower-Middle Income

- Upper-Middle Income

Community Forest Ownership

○ No

- Yes

* No Data

\section{Supplementary Figure 2}

Tropical population ${ }^{48}$ by increased carbon removal from reforestation $\left(\mathrm{tCO}_{2}\right)$ in a $\$ 20 \mathrm{tCO}_{2}{ }^{-1}$ tax scenario from 2020-2050 ${ }^{4}$. Panels are faceted by the percent of FLR opportunity $\operatorname{area}^{15}$ within a 3 arcminute pixel used to estimate carbon removal. Panel (a) includes all pixels, (b) includes pixels with $30 \%$ coverage or more, (c) includes pixels with $50 \%$ coverage or more, and (d) includes pixels with $100 \%$ coverage. 

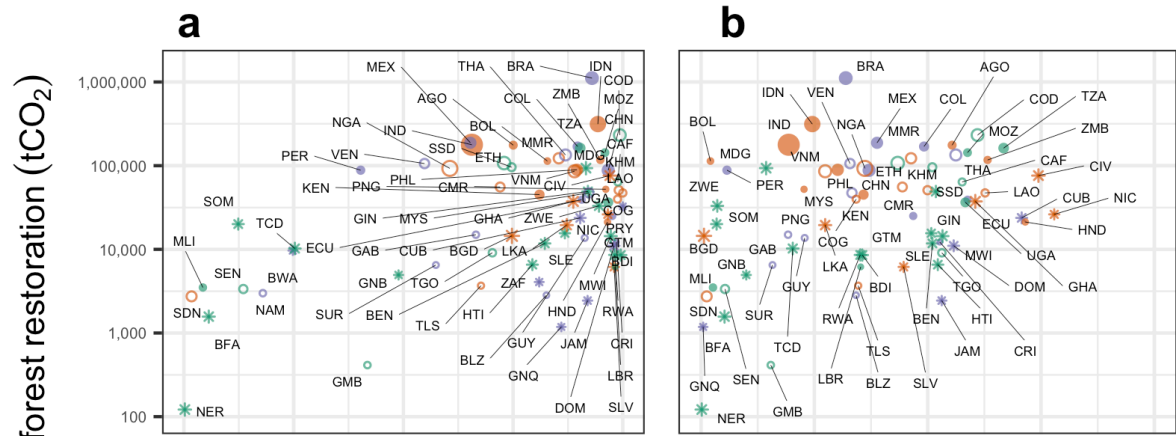

Income Level (WDI)

- Lower Income

- Lower-Middle Income

- Upper-Middle Income

Tropical Population

- $200,000,000$

d

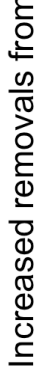

C

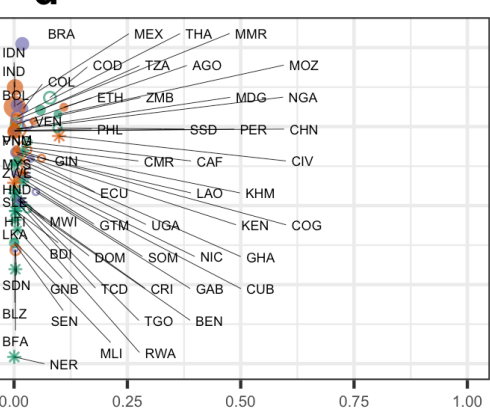

- $400,000,000$

$600,000,000$

Community Forest Ownership

№

- Yes

* No Data

\section{Supplementary Figure 3}

The proportion of tropical population ${ }^{48}$ by increased carbon removal from reforestation $\left(\mathrm{tCO}_{2}\right)$ in a $\$ 20 \mathrm{tCO}_{2}{ }^{-1}$ tax scenario from 2020-2050 ${ }^{4}$. Panels are faceted by the percent of FLR opportunity area ${ }^{15}$ within a 3 arcminute pixel used to estimate carbon removal. Panel (a) includes all pixels, (b) includes pixels with $30 \%$ coverage or more, (c) includes pixels with $50 \%$ coverage or more, and (d) includes pixels with $100 \%$ coverage. 


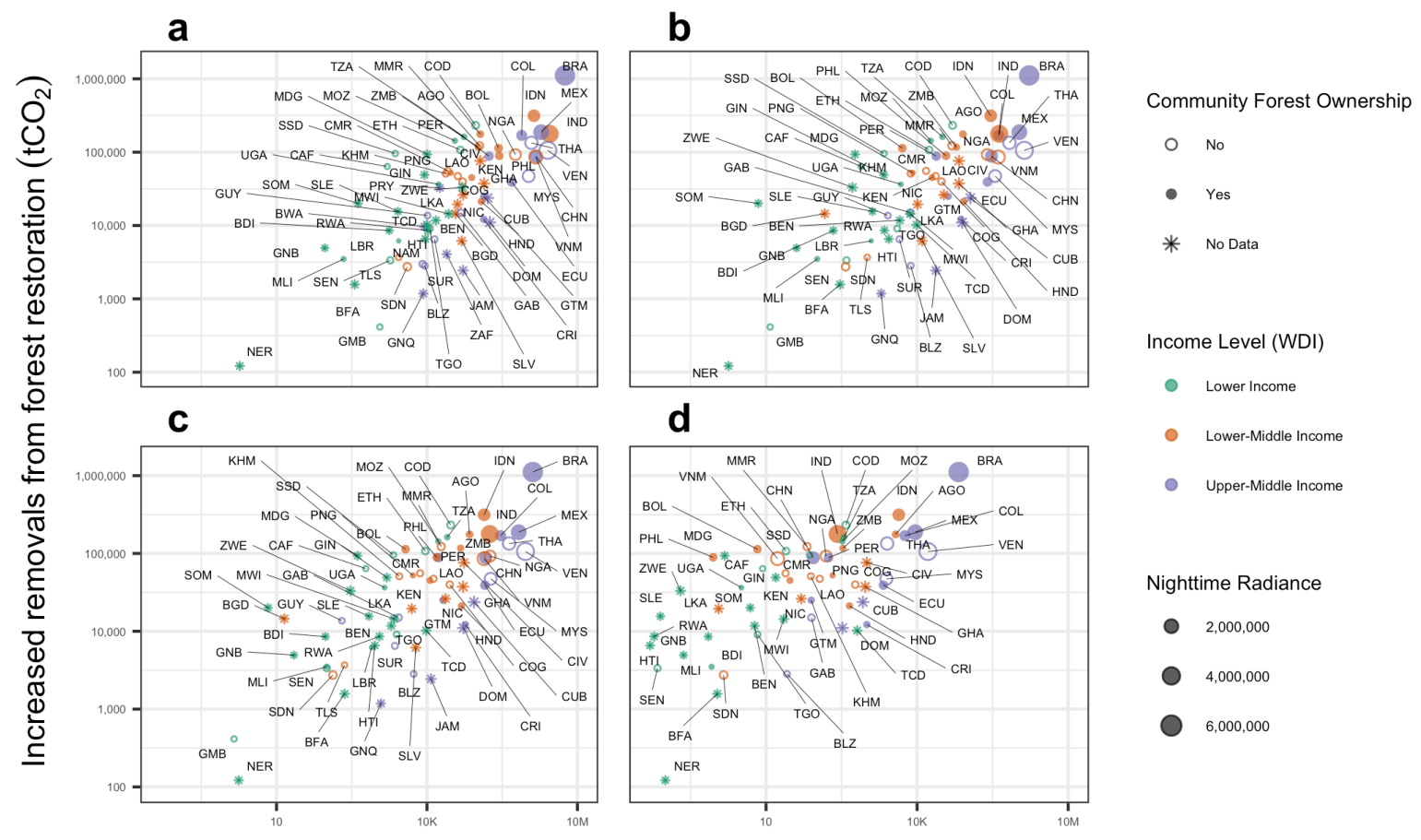

Radiance in Forest Restoration Areas

\section{Supplementary Figure 4}

Nighttime light radiance ${ }^{49}$ measured in (nanoWatts $/ \mathrm{cm}^{2} / \mathrm{sr}$ ) $\times 10^{9}$ by increased carbon removal from reforestation $\left(\mathrm{tCO}_{2}\right)$ in a $\$ 20 \mathrm{tCO}_{2}^{-1}$ tax scenario from 2020-2050 . Panels are faceted by the percent of FLR opportunity area ${ }^{15}$ within a 3 arcminute pixel used to estimate carbon removal. Panel (a) includes all pixels, (b) includes pixels with $30 \%$ coverage or more, (c) includes pixels with $50 \%$ coverage or more, and (d) includes pixels with $100 \%$ coverage. 


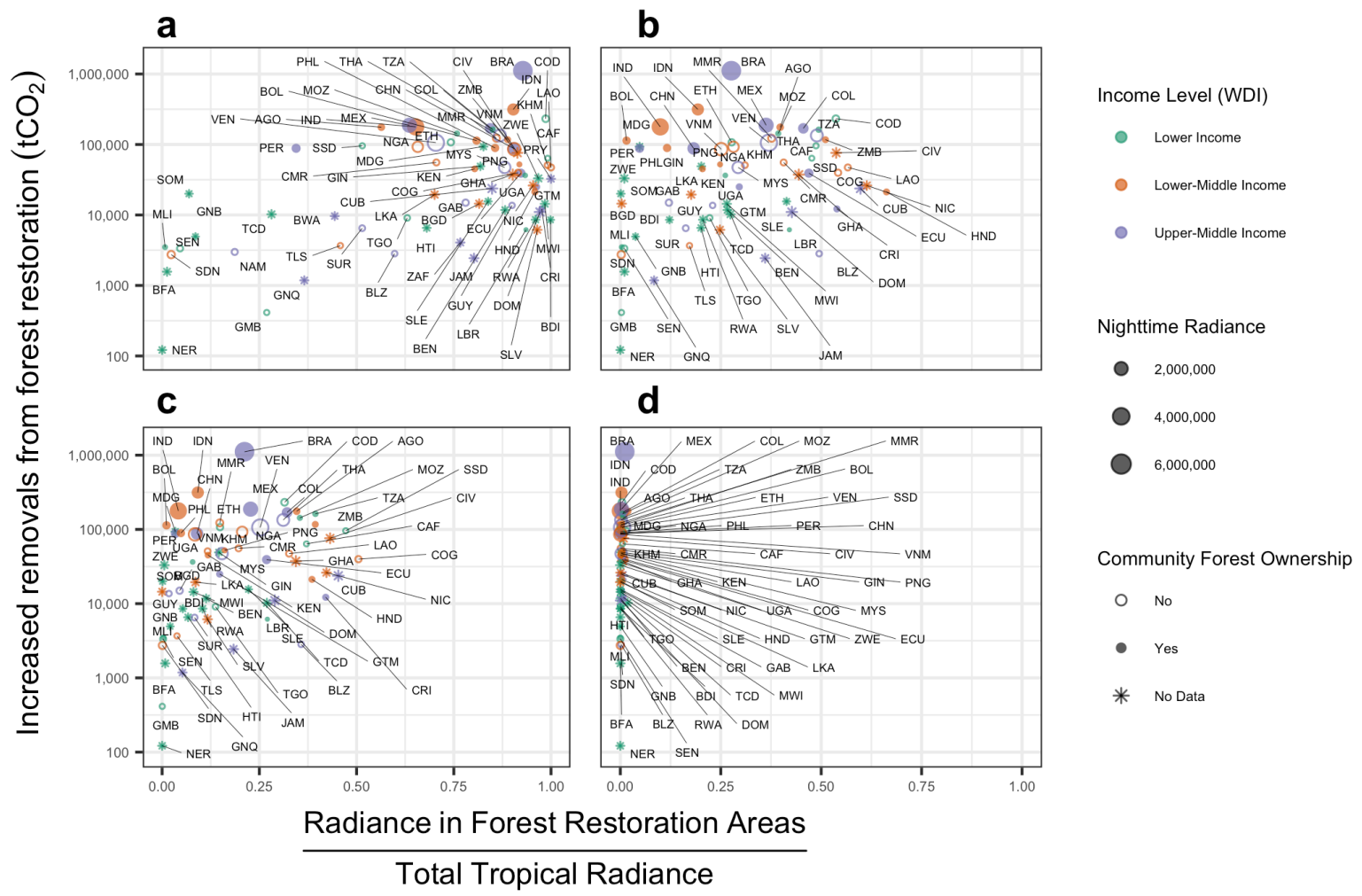

\section{Supplementary Figure 5}

The proportion of nighttime light radiance ${ }^{49}$ measured in (nanoWatts $/ \mathrm{cm}^{2} / \mathrm{sr}$ ) $\times 10^{9}$ by increased carbon removal from reforestation $\left(\mathrm{tCO}_{2}\right)$ in a $\$ 20 \mathrm{tCO}_{2}{ }^{-1}$ tax scenario from 2020-2050 . Panels are faceted by the percent of FLR opportunity area ${ }^{15}$ within a 3 arcminute pixel used to estimate carbon removal. Panel (a) includes all pixels, (b) includes pixels with $30 \%$ coverage or more, (c) includes pixels with $50 \%$ coverage or more, and (d) includes pixels with $100 \%$ coverage. 


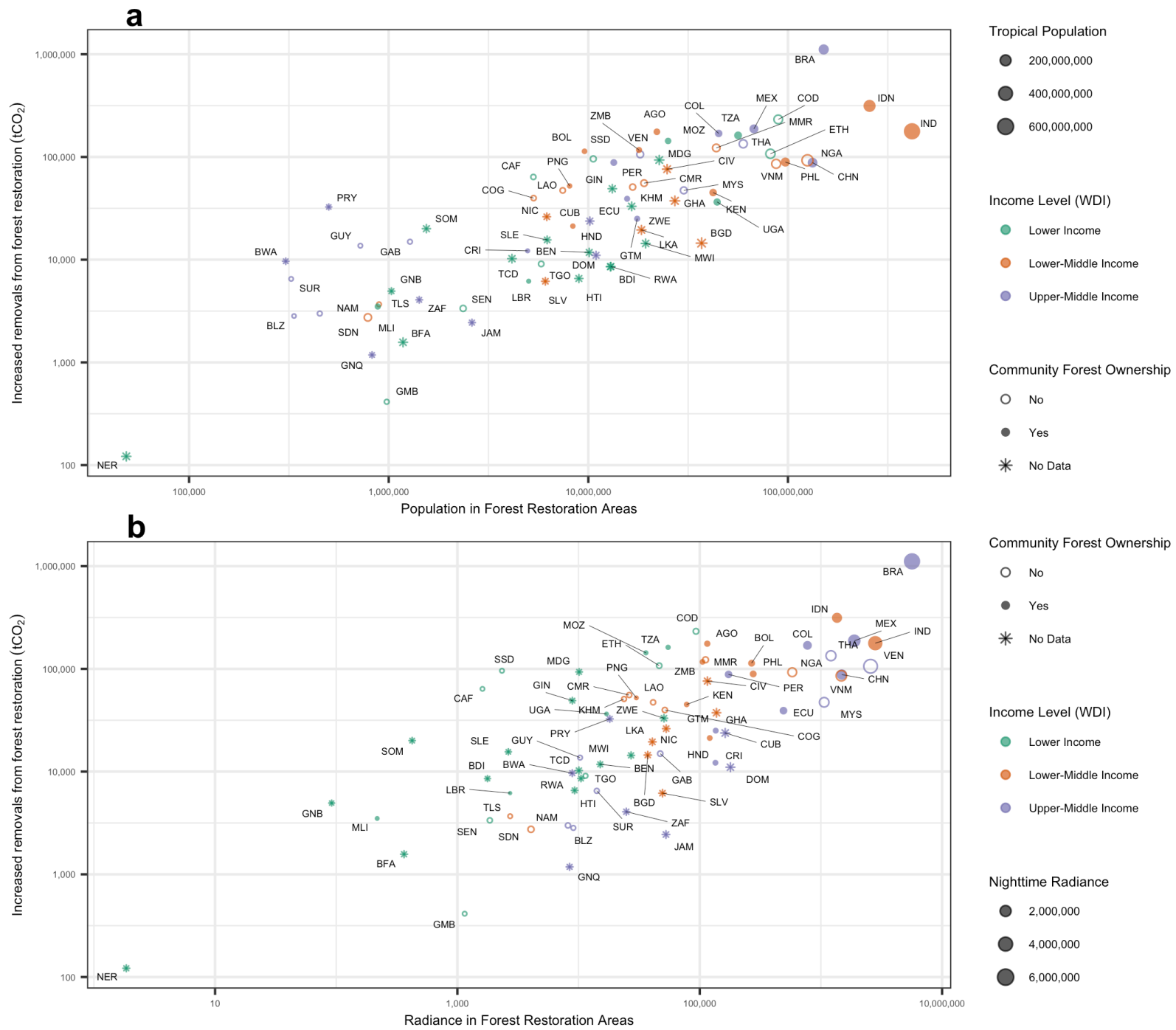

\section{Supplementary Figure 6}

Total population ${ }^{48}$ (a) and nighttime light radiance ${ }^{49}$ (b) within $7.1 \mathrm{~km}$ of increased carbon removal from forest restoration $\left(\mathrm{tCO}_{2}\right)$ between 2020 and 2050 in a $\$ 20 \mathrm{tCO}_{2}{ }^{-1}$ tax scenario ${ }^{4}$. Nighttime night radiance is measured in (nanoWatts $/ \mathrm{cm}^{2} / \mathrm{sr}$ ) $\times 10^{9}$. Panels (a) and (b) replicate Supplementary Figure 1 (a) and Supplementary Figure 3 (a), respectively. 


\begin{tabular}{|c|c|c|c|}
\hline Method of estimation & Datasets & Resolution & Population estimate \\
\hline $\begin{array}{l}\text { Population summed between } 23.4 \text { degrees } \\
\text { north and } 15 \text { degrees south }\end{array}$ & CIESIN $2019^{48}$ & $\begin{array}{l}30 \text { arcseconds } \\
(\sim 1 \mathrm{~km} \text { pixels })\end{array}$ & $3,003,677,668$ \\
\hline $\begin{array}{l}\text { Summed population within "Global map" } \\
\text { wide-scale and mosaic forest restoration } \\
\text { opportunities between } 23.4 \text { degrees north and } \\
15 \text { degrees south }\end{array}$ & $\begin{array}{l}\text { CIESIN } 2019^{48} \\
\text { Potapov et al. } \\
2011^{15}\end{array}$ & $\begin{array}{l}30 \text { arcseconds } \\
(\sim 1 \mathrm{~km} \text { pixels })\end{array}$ & $830,424,187$ \\
\hline $\begin{array}{l}\text { Summed population within "Global map" } \\
\text { restoration opportunities with at least } 30 \% \\
\text { tree-cover in } 2000 \text { between } 23.4 \text { degrees north } \\
\text { and } 15 \text { degrees south }\end{array}$ & $\begin{array}{l}\text { Hansen et al. } \\
2013^{45}, \text { CIESIN } \\
2019^{48}, \text { Potapov et } \\
\text { al. } 2011^{15}\end{array}$ & $\begin{array}{l}30 \text { arcseconds } \\
(\sim 1 \mathrm{~km} \text { pixels })\end{array}$ & $294,521,349$ \\
\hline $\begin{array}{l}\text { Summed population within "Global map" } \\
\text { restoration opportunities with at least } 50 \% \\
\text { tree-cover in } 2000 \text { between } 23.4 \text { degrees north } \\
\text { and } 15 \text { degrees south }\end{array}$ & $\begin{array}{l}\text { Hansen et al. } \\
2013^{45} \text {, CIESIN } \\
2019^{48}, \text { Potapov et } \\
\text { al. } 2011^{15},\end{array}$ & $\begin{array}{l}30 \text { arcseconds } \\
(\sim 1 \mathrm{~km} \text { pixels })\end{array}$ & $140,412,143$ \\
\hline $\begin{array}{l}\text { Summed population within pixels that estimate } \\
\text { any carbon removal from forest restoration } \\
\text { given a } \$ 20 \mathrm{tCO}_{2}^{-1} \text { incentive between } 23.4 \\
\text { degrees north and } 15 \text { degrees south }\end{array}$ & $\begin{array}{l}\text { Busch et al. } 2019^{4} \text {, } \\
\text { CIESIN } 2019^{48}\end{array}$ & $\begin{array}{l}3 \text { arcminutes } \\
(\sim 5.5 \mathrm{~km} \text { pixels })\end{array}$ & $2,372,546,672$ \\
\hline $\begin{array}{l}\text { Summed population within pixels that estimate } \\
\text { any carbon removal from forest restoration } \\
\text { given a } \$ 20 \mathrm{tCO}_{2}^{-1} \text { incentive, with at least } 30 \% \\
\text { pixel area covered by mosaic or wide-scale } \\
\text { forest restoration opportunities from the } \\
\text { "Global map," and between } 23.4 \text { degrees north } \\
\text { and } 15 \text { degrees south. }\end{array}$ & $\begin{array}{l}\text { Busch et al. } 2019^{4} \\
\text { CIESIN } 2019^{48} \\
\text { Potapov et al. } \\
2011^{15}\end{array}$ & $\begin{array}{l}3 \text { arcminutes } \\
(\sim 5.5 \mathrm{~km} \text { pixels })\end{array}$ & $1,012,654,847$ \\
\hline $\begin{array}{l}\text { Summed population within pixels that estimate } \\
\text { any carbon removal from forest restoration } \\
\text { given a } \$ 20 \mathrm{tCO}_{2}^{-1} \text { incentive, with at least } 50 \% \\
\text { pixel area covered by mosaic or wide-scale } \\
\text { forest restoration opportunities from the } \\
\text { "Global map," and between } 23.4 \text { degrees north } \\
\text { and } 15 \text { degrees south. }\end{array}$ & $\begin{array}{l}\text { Busch et al. } 2019^{4} \text {, } \\
\text { CIESIN } 2019^{48} \\
\text { Potapov et al. } \\
2011^{15}\end{array}$ & $\begin{array}{l}3 \text { arcminutes } \\
(\sim 5.5 \mathrm{~km} \text { pixels })\end{array}$ & $690,389,729$ \\
\hline $\begin{array}{l}\text { Summed population within pixels that estimate } \\
\text { any carbon removal from forest restoration } \\
\text { given a } \$ 20 \mathrm{tCO}_{2}^{-1} \text { incentive, with at least } \\
100 \% \text { pixel area covered by mosaic or wide- } \\
\text { scale forest restoration opportunities from the } \\
\text { "Global map," and between } 23.4 \text { degrees north } \\
\text { and } 15 \text { degrees south. }\end{array}$ & $\begin{array}{l}\text { Busch et al. } 2019^{4} \\
\text { CIESIN } 2019^{48} \\
\text { Potapov et al. } \\
2011^{15}\end{array}$ & $\begin{array}{l}3 \text { arcminutes } \\
(\sim 5.5 \mathrm{~km} \text { pixels })\end{array}$ & $38,256,811$ \\
\hline
\end{tabular}

\section{Supplementary Table 1.}

Population estimates within forest restoration opportunity areas by method, data, and spatial resolution. Estimates of additional carbon removal from forest restoration under a $\$ 20 \mathrm{tCO}_{2}{ }^{-1}$ tax are only within areas that were tree-covered in 2000 or $2010^{45}$. 


\begin{tabular}{|c|c|c|c|c|c|c|c|}
\hline \multirow[t]{2}{*}{ Country } & \multirow[t]{2}{*}{ Code } & \multicolumn{2}{|c|}{$\begin{array}{c}\text { Community Forest } \\
\text { Ownership }\end{array}$} & \multicolumn{2}{|c|}{$\begin{array}{c}\text { Community Forest } \\
\text { Designation }\end{array}$} & \multirow[t]{2}{*}{ FRO Area (Mha) } & \multirow[t]{2}{*}{$\begin{array}{l}\text { FRO Proximate } \\
\text { People (1E6) }\end{array}$} \\
\hline & & Evidence & Legal Basis & Evidence & Legal Basis & & \\
\hline Brazil & BRA & 1 & 1 & 1 & 1 & 220.11 & 51.86 \\
\hline Tanzania & TZA & 1 & 1 & 1 & 1 & 69.06 & 41.59 \\
\hline Indonesia & IDN & 1 & 1 & 1 & 1 & 53.17 & 66.68 \\
\hline Zambia & ZMB & 1 & 1 & 1 & 1 & 29.99 & 11.95 \\
\hline Mozambique & MOZ & 1 & 1 & 1 & 1 & 25.10 & 15.38 \\
\hline Kenya & KEN & 1 & 1 & 1 & 1 & 10.50 & 18.66 \\
\hline Ecuador & ECU & 1 & 1 & 1 & 1 & 9.63 & 10.15 \\
\hline Honduras & HND & 1 & 1 & 1 & 1 & 6.65 & 6.20 \\
\hline Guatemala & GTM & 1 & 1 & 1 & 1 & 6.43 & 8.43 \\
\hline Peru & PER & 1 & 1 & 1 & 1 & 5.35 & 1.90 \\
\hline Bolivia & $\mathrm{BOL}$ & 1 & 1 & 1 & 1 & 0.24 & 0.00 \\
\hline Uganda & UGA & 1 & 1 & 0 & 1 & 13.33 & 26.64 \\
\hline Mali & MLI & 1 & 1 & 0 & 1 & 2.30 & 0.54 \\
\hline Angola & $\mathrm{AGO}$ & 1 & 1 & 0 & 0 & 53.41 & 16.27 \\
\hline Mexico & MEX & 1 & 1 & 0 & 0 & 51.25 & 40.19 \\
\hline India & IND & 1 & 1 & 0 & 0 & 49.76 & 123.31 \\
\hline Colombia & $\mathrm{COL}$ & 1 & 1 & 0 & 0 & 36.52 & 24.67 \\
\hline China & $\mathrm{CHN}$ & 1 & 1 & 0 & 0 & 21.75 & 50.93 \\
\hline Papua New Guinea & PNG & 1 & 1 & 0 & 0 & 5.41 & 1.90 \\
\hline Costa Rica & CRI & 1 & 1 & 0 & 0 & 3.28 & 2.65 \\
\hline Cambodia & KHM & 0 & 1 & 1 & 1 & 10.55 & 8.41 \\
\hline South Sudan & SSD & 0 & 1 & 0 & 0 & 25.93 & 7.23 \\
\hline Togo & TGO & 0 & 1 & 0 & 0 & 3.63 & 4.39 \\
\hline Belize & BLZ & 0 & 1 & 0 & 0 & 0.78 & 0.14 \\
\hline Dem. Rep. of the Congo & COD & 0 & 0 & 1 & 1 & 103.94 & 54.91 \\
\hline Thailand & THA & 0 & 0 & 1 & 1 & 34.95 & 38.59 \\
\hline Ethiopia & ETH & 0 & 0 & 1 & 1 & 34.67 & 48.59 \\
\hline Myanmar & MMR & 0 & 0 & 1 & 1 & 25.28 & 23.73 \\
\hline Venezuela & VEN & 0 & 0 & 1 & 1 & 24.39 & 10.90 \\
\hline Laos & LAO & 0 & 0 & 1 & 1 & 8.37 & 4.66 \\
\hline Gabon & GAB & 0 & 0 & 1 & 1 & 3.12 & 0.37 \\
\hline Sudan & SDN & 0 & 0 & 1 & 1 & 2.05 & 0.57 \\
\hline Guyana & GUY & 0 & 0 & 1 & 1 & 0.36 & 0.18 \\
\hline Gambia & GMB & 0 & 0 & 1 & 1 & 0.28 & 0.36 \\
\hline Nigeria & NGA & 0 & 0 & 0 & 1 & 34.00 & 74.75 \\
\hline Central African Rep. & CAF & 0 & 0 & 0 & 1 & 21.14 & 3.09 \\
\hline Rep. of Congo & COG & 0 & 0 & 0 & 1 & 13.10 & 1.84 \\
\hline Malaysia & MYS & 0 & 0 & 0 & 0 & 10.28 & 10.85 \\
\hline Senegal & SEN & 0 & 0 & 0 & 0 & 1.46 & 0.92 \\
\hline East Timor & TLS & 0 & 0 & 0 & 0 & 0.74 & 0.46 \\
\hline Suriname & SUR & 0 & 0 & 0 & 0 & 0.11 & 0.09 \\
\hline
\end{tabular}

\section{Supplementary Table 2.}

Country-level information and opportunities for community-based FLR. Countries are listed in descending order based on evidence and legal basis for community forest ownership, evidence and legal basis for community forest designation, and forest reforestation opportunity (FRO) $\operatorname{areas}^{4,15,43,48,53}$. FRO areas ( 3 arcminute pixels) are between $23.4^{\circ} \mathrm{N}$ and $15^{\circ} \mathrm{S}$ with any modeled carbon removal from restoration under a $\$ 20 \mathrm{tCO}_{2}{ }^{-1}$ tax scenario ${ }^{4}$ and at least $30 \%$ coverage of wide-scale or mosaic forest restoration opportunities identified in the "Global map of forest landscape restoration" ${ }^{15}$. Population is estimated within FRO areas ${ }^{48}$. 


\begin{tabular}{|c|c|}
\hline Country & Code \\
\hline Algeria & $\overline{D Z A}$ \\
\hline Angola & AGO \\
\hline Argentina & ARG \\
\hline Aruba & $\mathrm{ABW}$ \\
\hline Australia & AUS \\
\hline Bahamas & BHS \\
\hline Bangladesh & BGD \\
\hline Belize & BLZ \\
\hline Benin & BEN \\
\hline Bolivia & $\mathrm{BOL}$ \\
\hline Botswana & BWA \\
\hline Brazil & BRA \\
\hline British Virgin Islands & VGB \\
\hline Brunei & BRN \\
\hline Burkina Faso & BFA \\
\hline Burundi & BDI \\
\hline Cambodia & KHM \\
\hline Cameroon & CMR \\
\hline Cayman Islands & CYM \\
\hline Central African Republic & $\mathrm{CAF}$ \\
\hline Chad & TCD \\
\hline Chile & CHL \\
\hline China & $\mathrm{CHN}$ \\
\hline Colombia & $\mathrm{COL}$ \\
\hline Comoros & $\mathrm{COM}$ \\
\hline Costa Rica & CRI \\
\hline Côte d'Ivoire & CIV \\
\hline Cuba & CUB \\
\hline Curaçao & CUW \\
\hline Democratic Republic of the Congo & COD \\
\hline Djibouti & DJI \\
\hline Dominican Republic & DOM \\
\hline East Timor & TLS \\
\hline Ecuador & ECU \\
\hline Egypt & EGY \\
\hline El Salvador & SLV \\
\hline Equatorial Guinea & GNQ \\
\hline Eritrea & ERI \\
\hline Ethiopia & ETH \\
\hline Gabon & GAB \\
\hline Gambia & GMB \\
\hline Ghana & GHA \\
\hline Grenada & GRD \\
\hline Guatemala & GTM \\
\hline Guinea & GIN \\
\hline Guinea-Bissau & GNB \\
\hline Guyana & GUY \\
\hline Haiti & HTI \\
\hline Honduras & HND \\
\hline
\end{tabular}

\begin{tabular}{|c|c|}
\hline Country & Code \\
\hline Hong Kong & $\mathrm{HKG}$ \\
\hline India & IND \\
\hline Indonesia & IDN \\
\hline Jamaica & JAM \\
\hline Kenya & KEN \\
\hline Laos & LAO \\
\hline Liberia & LBR \\
\hline Libya & LBY \\
\hline Macao & MAC \\
\hline Madagascar & MDG \\
\hline Malawi & MWI \\
\hline Malaysia & MYS \\
\hline Maldives & MDV \\
\hline Mali & MLI \\
\hline Mauritania & MRT \\
\hline Mexico & MEX \\
\hline Mozambique & $\mathrm{MOZ}$ \\
\hline Myanmar & MMR \\
\hline Namibia & NAM \\
\hline Nicaragua & NIC \\
\hline Niger & NER \\
\hline Nigeria & NGA \\
\hline Palau & PLW \\
\hline Panama & PAN \\
\hline Papua New Guinea & PNG \\
\hline Paraguay & PRY \\
\hline Peru & PER \\
\hline Philippines & PHL \\
\hline Puerto Rico & PRI \\
\hline Republic of Congo & $\mathrm{COG}$ \\
\hline Rwanda & RWA \\
\hline Sao Tome \& Principe & STP \\
\hline Saudi Arabia & SAU \\
\hline Senegal & SEN \\
\hline Seychelles & SYC \\
\hline Sierra Leone & SLE \\
\hline Singapore & SGP \\
\hline Sint Maarten & SXM \\
\hline Solomon Islands & SLB \\
\hline Somalia & SOM \\
\hline South Africa & ZAF \\
\hline South Sudan & SSD \\
\hline Sri Lanka & LKA \\
\hline Sudan & SDN \\
\hline Suriname & SUR \\
\hline Taiwan & TWN \\
\hline Tanzania & TZA \\
\hline Thailand & THA \\
\hline Togo & TGO \\
\hline
\end{tabular}

\begin{tabular}{ll} 
Country & Code \\
\hline Trinidad \& Tobago & TTO \\
Uganda & UGA \\
Venezuela & VEN \\
Vietnam & VNM \\
Virgin Islands, U.S. & VIR \\
Yemen & YEM \\
Zambia & ZMB \\
Zimbabwe & ZWE \\
\hline
\end{tabular}

Supplementary Table 3 .

A list of all countries that appear in the analysis (including SI) with country name and World Bank country code. 